\title{
An Efficient Method to Compute Partial Atomic Charges of Large Molecules Using Reassociation of Fragments
}

\author{
Jung-Goo Lee, ${ }^{*}$ Ho Young Jeong, ${ }^{\dagger}$ and Hosull Lee ${ }^{\ddagger}$

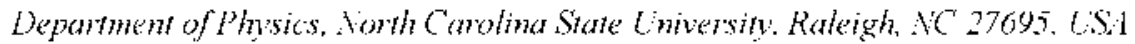 \\ ${ }^{\dagger}$ Gatsby Computational Vemoscience Lnit, Lniversity College London. London WCIN $3 \mathrm{AR}$, LK \\ 'Numho Chemical Laboratories. 1'O. Box 6f, Haseong. Daejeon 305-600, Nomea \\ Received Hay 2, 2002
}

\begin{abstract}
Coulson (7.INDO), Mulliken (MP2/6-3I G*) and Natural (MP2/6-3/G*) population analy wes ol sereral large molecules nere perfomed by the Fragment Reassociation (FR) method. The agrement between the conventional 7.IND) (or conventional MP2) and FR-7.INT)O (or FR-MP2) charges of these molecules was weellent. The standard deviations of the FR-7.INDO net atomic charges from the conventional 7.INDO net atomic charges were 0.0008 for $\mathrm{C}_{16} \mathrm{H}_{22}\left(32\right.$ aloms), 0.0012 for $\mathrm{NH}_{2}-\mathrm{C}_{16} \mathrm{O}_{2} \mathrm{H}_{2}-\mathrm{COOH}$ (53 atoms), 0.0014 for $\mathrm{NH}_{3}{ }^{-} \mathrm{C}_{16} \mathrm{O}_{2} \mathrm{H}_{2}-\mathrm{COOH}\left(54\right.$ atoms), 0.0017 for NH $\mathrm{NH}_{2} \mathrm{C}_{16} \mathrm{O}_{2} \mathrm{H}_{2}-\mathrm{COO}$ (52 atoms), 0.0019 lor $\mathrm{NH}_{3}{ }^{+}-\mathrm{C}_{16 \mathrm{O}_{2}} \mathrm{H}_{2} \mathrm{C}^{-}$ $\mathrm{COO}(5.3 \mathrm{atoms}), 0.0024$ lor a conjugaled model $\left(\mathrm{O}=\mathrm{C} \cdot \mathrm{H}-(\mathrm{C} \cdot \mathrm{H}=\mathrm{C} \cdot \mathrm{H})_{5}-\mathrm{C}=\mathrm{O}-(\mathrm{CH}=\mathrm{CH})_{2}-\mathrm{CH}=\mathrm{CH}\right)_{2}, 118$

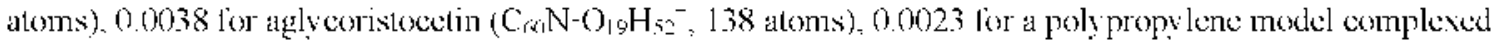
with a zirconocene calaly st $\left(\mathrm{C}_{6 \mathrm{~s}} \mathrm{H}_{12} 7 \mathrm{r}^{+}, 190\right.$ atoms) and 0.0013 for magainin $\left(\mathrm{C}_{112} \mathrm{~N}_{2} \mathrm{O}_{2 \times} \mathrm{SH}_{17^{-}}, 347\right.$ atoms). ruspetively. The standard deviations of the FR-MP2 Mulliken (or Natural) partial atomic charges from the comventional ones were 0.0016 (or 0.0016 ) for $\mathrm{C}_{10} \mathrm{H}_{2} 0.0019$ (or 0.0018 ) for $\mathrm{NH}_{2}-\mathrm{C}_{16} \mathrm{O}_{2} \mathrm{H}_{2}-\mathrm{COOH}_{\text {and }}$ 0.0033 (or 0.0023$)$ for $\mathrm{NH}_{3}^{-}-\mathrm{C}_{16} \mathrm{O}_{2} \mathrm{H}_{2}-\mathrm{COO}$, respectively. Thexe errors were attributed to the shape of molecules, the choice of tragments and the degree ol ionic eharacters of molecules as well as the ehoice of mothods. The CPIJ time of aglycoristocetin, conjugated model, polypropylene model complexed with zirconocene and magainin compuled by the FR-7.INDO nethod was respectively 2,4,6 and 21 tines laster than that by the nomeal 7.INDO method. The CPI time of $\mathrm{NH}_{2}-\mathrm{C}_{16} \mathrm{O}_{2} \mathrm{H}_{28}-\mathrm{COOH}^{\circ}$ and $\mathrm{NH}_{3}{ }^{\prime}-\mathrm{C}_{16} \mathrm{O}_{2} \mathrm{H}_{2 \times}-\mathrm{COOO}^{-}$ compuled by the FR-MP2 method was, respectively, 6 and 20 times laster than that by the nomal MP2 methed. The largest molecule calculated by the FR-7.INDO method was B-DNA (766 atoms). These results will enable us to compute atomic charges of huge molecules near luture.
\end{abstract}

Key Words : l'opulation analysis, fragment reassociation

\section{Introduction}

$\mathrm{Net}$ atomic charges or partial atomic charges play a significant role to analyze the polarization cffects of molccules and the electrostatic intcractions in chemical reactions. Also. atomic charges are widely used as one of the QSAR paramelers for dnig design. The elcctrostatic potential is very important as onc of the force ficlds for molccular modeling. Classically. atomic charges can be obtaincd. for cxample. by the clarge equilibration melhod. " where cmpirical parameters such as atomic ionization polentials. electron affinitics and atomic radii are cmployed. Quantum meclanically. many attempts ${ }^{3-21}$ have becil made to calculate atomic clarges or to perform population analyses. Typical population analyses are based on the basis sel (1he Coulson. Mulliken ${ }^{3}$ and Natural' ${ }^{\prime}$ population amalysis. or bricfly CPA. MPA and NPA). 1he ElcclroStatic Polential (ESP). ${ }^{1-13}$ and the wave function (the topological theory of Atoms In Molccules (AIM)). ${ }^{1 \cdot-16}$ The Coulson and Mulliken clarges are simple to calculate but vary a lot depending on basis functions. On the olher hand. ESP and AIM charges are rather independent of

"To whom comespondenes should be addressed. Phone: +919-5130317: Fax: +919-513-4804: E-mail jglec änemo.phrsies.nesucdu basis sel but take more CPU time. Natural charges ${ }^{3^{-2}}$ are based on the natural atomic orbital whose derivation in olyes diagonalizing the localized block of the electron density matrix with atomic basis sel. Natural charges are basis sel independent and take slightly more CPU time than Mulliker charges do. Therefore. for analysis purposes the NPA procedure is an atractive method. but for modeling purposes (i.e. force ficld clarges) ESP clarges are clearly the logical choice. Exen in NPA. howerer. computations of a large molecular system is still limited to less than 100 atoms at the MP2 level with the 6-.31G* basis set. and to a few lundred atoms at the Hartrec-Fock (HF) level. As a praclical serisc. atomic clarges of large molecules oblained by NPA or exer CPA and MPA are used for the analyses described carlicr.

Some time ago. we proposed so called the Fragment Density Matrix (FDM) melhod"- where the HF electrostatic potentials of medium (29 10 32 atomic) molecules were constructed from the density matrix elements of two fragnent molecules. When the FDM method is applied to the calculations of CPA. MPA and NPA. atomic charges of large molecules are obtained by the reassociation of atomic charges of fragments mather than by that of density matrix elements of fragments. as derived in the next section. Therefore. the CPU time of the Coulson. Mulliken or 
Natural charges expressed by the method of Fragment Reassociation. or the FR method, will become even shorter than that obtained by the FDM method.

In this work. the Coulson charges of molecules with up to 766 atoms or the Mulliken and Natural charges of molecules with up to 53 atoms were obtained by the semiempinical (ZINDO) or ab initio (MP2/6-31G*) calculations using the FR method. We will abbreviate these methods as FR-ZINDO and FR-MP2. respectively: Here, the FR-MP2 method means either FR-MP2 MPA or FR-MP2 NPA computation, or collectively both calculations. The difference between charges obtained by the FR-ZINDO (or FR-MP2) method and those obtained by the comentional ZINDO (or MP2 method) is also discussed. We have chosen neutral, cationic. anionic. and zwitterionic models as well as a conjugated model as target molecules.

\section{Computational Details}

A. Net Atomic Charges. Net atomic changes mainly consist of the following four types. The first one is by the Coulson type.

$$
q_{.4}=Z_{. i}-\sum_{\mu t \in .-1} P_{\mu \mu}
$$

where $q_{A t}$ is the net atomic charge on $A^{t / s}$ nucleus. $Z_{A}$ the charge of $A^{\text {rh }}$ nucleus, and $P_{\mu w}$ the density matrix given by the summation of multiplications of M.O. coefficients (c:) over occupied orbitals:

$$
P_{\mu \mu}=\sum_{i-1}^{N C c^{\circ}} c_{\mu j} c_{\nu i} .
$$

The second one is by the Mulliken type.

$$
q_{d j}=Z_{. j}-\sum_{\mu \in . \dagger} \sum_{v \in . i} P_{\mu, j} S_{\mu \nu}
$$

where $S_{\mu \nu}$ is the overlap matrix. Therefore. the Mulliken net atomic charges give similar values to the Coulson net atomic charges

The third one is by the Natural charge.

$$
q_{. i}=Z_{.-}-N_{-i}
$$

Here. $F_{A}$ is the total number of electrons on center $A$ and obtained from the sum of the diagonal elements $\left(\Sigma_{\mu \in . .1} q_{\mu}\right)$ of the first-order reduced density matrix in the orthonormal Natural Atomic Orbital (NAO) basis. The NAOs on each center A typically separate into two distinct sets: (1) the high-occupancy natural minimal basis set. equal in number and type to the nominal minimal basis of occupied HF AOs in the ground state configuration and (2) the low-occupancy natural Rydberg basis set. corresponding to all residual orbitals lying outside the formal valence shell.

The fourth one, which represents the net atomic charges more accurately than the previous three methods is by the ESP fit

$$
\left(q_{1} \cdot q_{2} \ldots q_{X}\right)=R^{-1} I_{i}
$$

In eq 5, R is the matrix of inverse distance from grid point to nuclei. and $r_{i}$ is the electrostatic potential surrounding a molecule at a grid point, $r_{i}$. given by

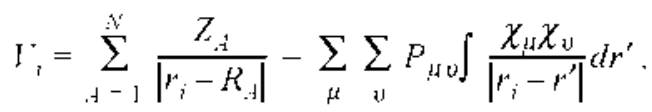

Here. $X$ is the number of atoms in a molecule, $R_{t}$ the position of $A^{t h}$ nucleus. $r^{\prime}$ the position of electron. and $\chi_{i t}$ and $\chi_{u}$ are the basis functions used.

ln all these four types, density matrix terms of a molecule have to be computed after SCF iteration. Therefore, it takes a large amount of cpu time to calculate atomic charges of large molecules by ordinary SCF methods. In order to avoid the computation of whole density matrix. the Fragment Density Matrix (FDM) method was proposed and explained in the following section.

B. FDM Approach. lnstead of calculating accurate density matrix elements for a large molecular system. approximate density matrix terms $P_{\mu \nu}^{\prime}$ ', are constructed from those of two or more fragment molecules in the FDM method. In the evaluation of $P_{\mu u}$ '. it is important for all atoms to include neighboring effects (usually 2 to + nearest neighbors for a neutral molecule). The approximate density matrix elements $P_{\mu D}^{\prime}$ are then scaled in order to satisfy the total atomic charge requirement. Therefore, the final density matrix $J_{\mu u}{ }^{\prime}$ can be expressed by

$$
P_{\mu v}=k_{\mu u} P_{\mu \nu}^{\prime}
$$

where $k_{k u}$ are the scale factors. Or more simply,

$$
P_{\mu \nu}=k P_{u \nu^{\prime}}
$$

In eq. $8, k$ is a constant scale factor and the optinum $k\left(=k_{0}\right)$ is derived as

$$
k_{n}=\frac{\lambda_{S}-\alpha_{S}}{\lambda_{S}-\left.\Delta q\right|_{k-1}},\left.\quad \Delta q\right|_{k-1}=\left.\sum_{.1-1}^{N} q_{. J}\right|_{k-1}
$$

Here. $\psi_{s}$ (and $\alpha_{s}$ ) are the summation of atomic numbers (and net atomic charges) over all atoms. The constant. $\alpha_{s \text {. is equal }}$ to 0 for a neutral moleculc. +1 for a cationic compound. and -1 for an anionic compound. respectively: $\left.\Delta q\right|_{k-1}$ represents the summation of net atomic charges over all atoms when $k=1$.

Since the FDM method consinucis the density matrix. ${ }^{2.3}$ it can be applicd to craluate atomic charges of the CoulsonType. Mulliken-Type. Natural-Tỵpe. potential deri ed electrostatic-Type and other types in which atomic charges are derived from density matrix elements. When the FDM method is applied to compute the Coulson. Mulliken and Natural atomic charges. these charges can be cxpressed nol by the density matrix elements of fragments but by partial atomic charges of fragments as derived next. This method. or the Fragment Reassociation (FR) incthod. will further reduce the cpu time for calculations of the Coulson. Mulliken and Natural net atomic charges. Hereafter. "net atomic charges" are abbreviated as "cliarges" for simplicity unless specificd 
otherwise.

C. FR Method to Compute Coulson, Mulliken and Natural Charges. First. the Coulson charge is considered. The Coulson charge on atom $A$ obtained by the FDM method. $q_{4}^{\prime}$, is

$$
q_{i j}^{\prime}=Z_{.4}-\sum_{\mu \in d i} P_{\mu j}^{\prime}
$$

From eq. 1 and eq. 8.

$$
\begin{aligned}
k q_{A j}^{\prime} & =k Z_{. j}-\sum_{\mu \in A} P_{\mu \mu}^{\prime} \\
& =k Z_{A}-\left(Z_{A j}-q_{. j}\right)
\end{aligned}
$$

Then.

$$
q_{. j}=Z_{. j}-k\left(Z_{. j}-q_{. j}{ }^{\prime}\right)
$$

Therefore. $q$ is expressed by the charges of the fragments $q_{i}^{\prime}$ and the scale factor $k$ withoul including the density matrix terins.

The Mulliken charge is obtained in a similar manner if one assumes that

$$
k=\frac{\sum_{\mu \in A} \sum_{\nu \in d} P_{\mu \mu \nu} S_{\mu \nu}^{\prime}}{\sum_{\mu \in A} \sum_{\nu \in .1} P_{\mu \nu}{ }^{\prime} S_{\mu \nu}^{\prime}}
$$

Then.

$$
\begin{aligned}
\mathscr{C}_{A} & =Z_{A}-k \sum_{\mu \in A} \sum_{D \in A} P_{\mu \nu}{ }^{\prime} S_{H U}^{\prime} \\
& =Z_{. A}-k\left(Z_{. i}-q_{. A}\right)
\end{aligned}
$$

Therefore, the Mulliken charge (eq. 16) is expressed by the same equation as the Coulson charge (eq. 13).

The Natural charge is also obtained in a similar way if one assumes that

$$
k=\frac{N_{i}^{\prime}}{N_{. i}^{\prime}}
$$

Then.

$$
\begin{aligned}
q_{. i} & =Z_{. j}-k A_{. j}^{\prime} \\
& =Z_{.1}-k\left(Z_{.1}-q_{. j}^{\prime}\right)
\end{aligned}
$$

Therefore, the Natural charge (eq. 19) is also expressed by the same equation as the Coulson charge (eq. 13). Although our FR method employs eq. 9 and eq. 13, other methods of reassociation of fragments were proposed elsewhere. ${ }^{-7-26}$

D. Target Molecules and Fragments. A non-polar molecule $\left(\mathrm{C}_{1 i} \mathrm{H}_{2}\right)$ was taken to investigate the error between the normal- and FR-ZINDO charges. Then. a hypothetical molecule $\left(\mathrm{NH}_{2}-\mathrm{C}_{16} \mathrm{O} \_\mathrm{H}_{-x}-\mathrm{COOH}\right)$ was taken to study the error between the ZINDO and FR-ZINDO charges by the polar effect. Furthermore the charges of cationic $\left(\mathrm{NH}_{3}{ }^{\prime}-\right.$ $\left.\mathrm{C}_{16} \mathrm{O}_{2} \mathrm{H}_{2}-\mathrm{COOH}\right)$. anionic $\left(\mathrm{NH}_{2}-\mathrm{C}_{16} \mathrm{O}_{2} \mathrm{H}_{2}-\mathrm{COO}^{-}\right)$and zwitterionic $\left(\mathrm{NH}_{3}{ }^{-} \mathrm{C}_{16} \mathrm{O}_{2} \mathrm{H}_{2 k}-\mathrm{COO}^{-}\right)$forms were calculated to estimate the error by the ionic effect. The geometries of above compounds were arbitrarily chosen. The charges of several larger compounds, a conjugated model $(\mathrm{O}=\mathrm{CH}$ $(\mathrm{CH}=\mathrm{CH})_{15}-\mathrm{C}=\mathrm{O}-(\mathrm{CH}=\mathrm{CH})_{12}-\left(\mathrm{CH}=\mathrm{CH}_{2}\right)$. or $\left.\mathrm{C}_{5} \mathrm{O}_{2} \mathrm{H}_{5} \times\right)$. aglyconistocetin $\left(\mathrm{C}_{60} \mathrm{~N}-\mathrm{O}_{1} \mathrm{H}_{52}\right)$, a polypropylene model complexed with zirconocene $\left(\mathrm{Zr}^{\prime}\left(\mathrm{C}_{5} \mathrm{H}_{2} \mathrm{C}_{1} \mathrm{H}_{8} \mathrm{CH}_{2}\right)_{2}\left(\mathrm{CH}_{2}-\right.\right.$ $\left.\mathrm{CH}-\mathrm{CH}_{3}\right)_{1.1} \mathrm{H}\left(\mathrm{CH}_{2}=\mathrm{CH}-\mathrm{CH}_{3}\right)$. or $\left.\mathrm{C}_{648} \mathrm{H}_{12} \mathrm{Zr}\right)$ and magainin $\left(\mathrm{C}_{11} \mathrm{~N}_{\mho} \mathrm{O}_{2 \times} \mathrm{SH}_{1: 3}\right)$. were computed by both FR-ZINDO and normal- ZINDO methods. All models had no symumetry although $\mathrm{C}_{1}\left(\mathrm{H}_{22}\right.$ and the conjugated model had nearly planar symmetry: ZINDO calculations of the target and fragment molecules except for B-DNA were carried out by the ZINDO program ${ }^{-}$in Cerius2 on Silicon Graphics (RI0000) workstations. Because the maximum number of atoms in the ZINDO program is limited to 400 . calculations of only BDNA fragments were carried out. MP2 computations of $\mathrm{C}_{1,1} \mathrm{H}_{22}, \mathrm{NH}_{2}-\mathrm{C}_{10} \mathrm{O}_{2} \mathrm{H}_{2 x}-\mathrm{COOH}, \mathrm{NH}_{3}{ }^{-} \mathrm{C}_{16} \mathrm{O}_{2} \mathrm{H}_{2 x}-\mathrm{COO}^{-}$and their fragments were done by the Gaussiant 48 package ${ }^{2 /}$ on a Cray-C94 at the KUMHO Supercomputing Center.

lin FR calculations, the charges of first target molecule. $\mathrm{C}_{10} \mathrm{H}_{22}$, were constructed from those of two $\mathrm{C}-\mathrm{H}_{16}$ fragment molecules as shown in Figure 1. In other words. the charges of the atoms left to the junction (solid line) of $\mathrm{C}_{1} \mathrm{H}_{2 z}$ (Figure la) were taken from those left to the junction of the left fragment molecule (Figure $\mathrm{Ib}$ ) while charges of the atoms right to the junction of $\mathrm{C}_{11} \mathrm{H}_{2 z}$ (Figure la) were taken from those right to junction of the right fragment molecule (Figure lc). To consider the neighboring effect. both right and left $\mathrm{C}-\mathrm{H}_{15}$ fragments included 2 nearest neighbors (2 nearest carbons and 5 nearest hydrogens) from the junctions as shown in Figure $\mathrm{lb}$ and $\mathrm{lc}$. For example. in FR-ZINDO calculations, Coulson charges of $\mathrm{C}_{1}, \mathrm{H}_{22} \cdot\left(\mathrm{q}_{1} . \mathrm{q}_{2} \ldots . . \mathrm{q}_{1} \mathrm{q}_{2} \mathrm{q}_{1}\right.$. ... $\mathrm{q}_{32}$ : here the atomic numbering being shown in Figure la). were constructed from those of two fragments: (i)

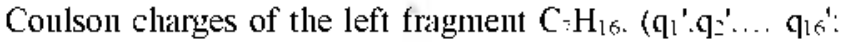
Figure $(b)$ and (ii) Coulson charges of the right fragment. $\mathrm{C}=\mathrm{H}_{16}$ ( $\left(\mathrm{q}_{1}{ }^{-}, \ldots \mathrm{q} \mathrm{q}_{3:}:\right.$ Figure $\left.\mathrm{Ic}\right)$. Each charge. $\mathrm{q}_{\mathrm{A}}(\mathrm{A}=1,2 \ldots$ 16. 17. ... or 32), was calculated from q $t^{\prime}$ according to eq.

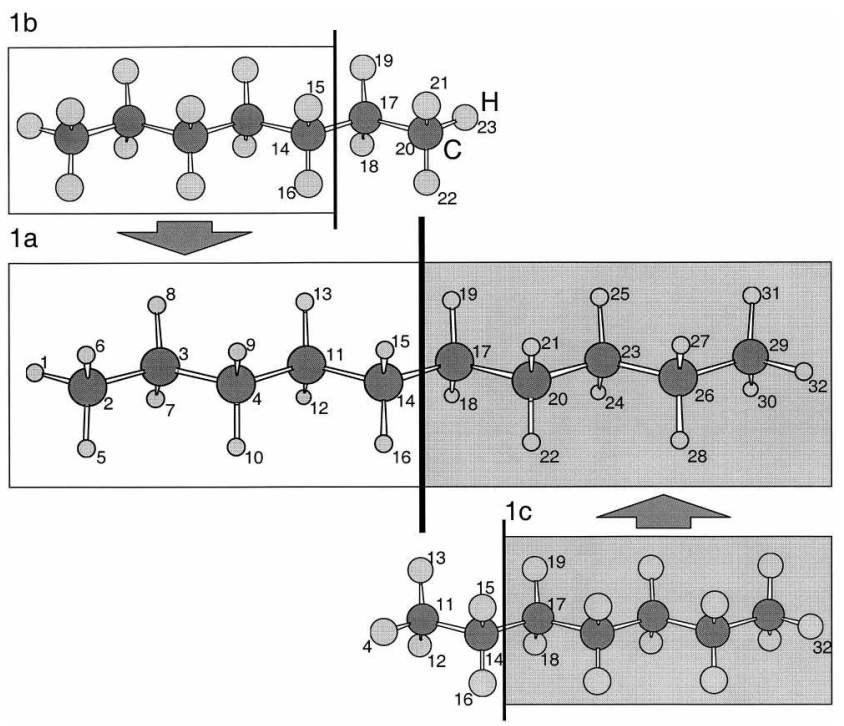

Figure 1. $\mathrm{C}_{10 \mathrm{I}} \mathrm{I}_{22}(\mathrm{a})$ and its Iragments (b. c) 


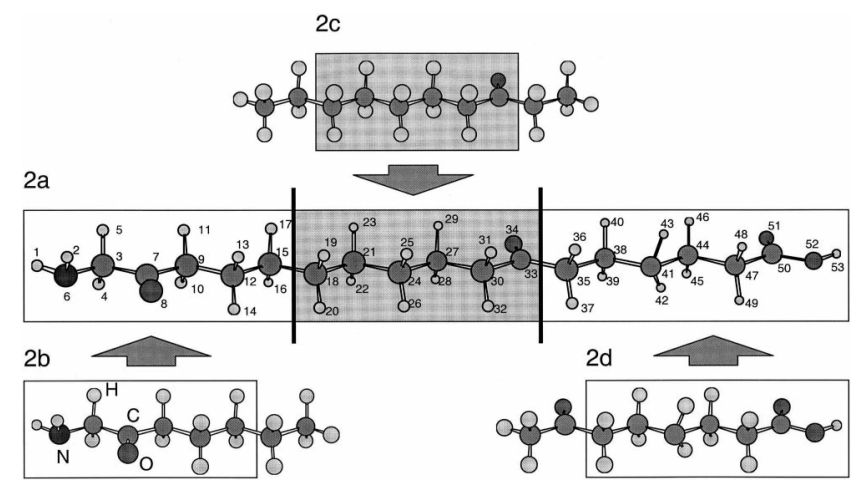

Figure 2. $\mathrm{NH}_{2}-\mathrm{C}_{16} \mathrm{O}_{2} \mathrm{H}_{28}-\mathrm{COOH}$ (a) and its fragment (b. c. d).

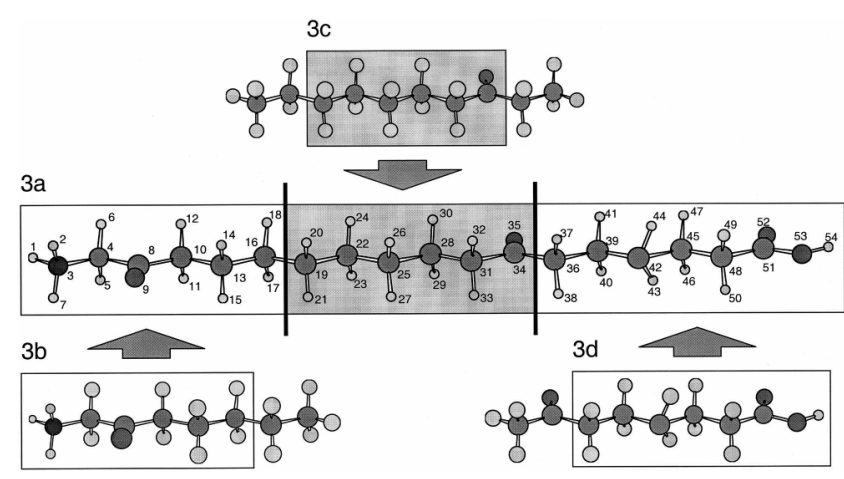

Figure 3, $\mathrm{NH}_{5}^{-}-\mathrm{C}_{10} \mathrm{O}_{2} \mathrm{I}_{28}-\mathrm{COOH}$ (a) and its Iragment (b. c. d).

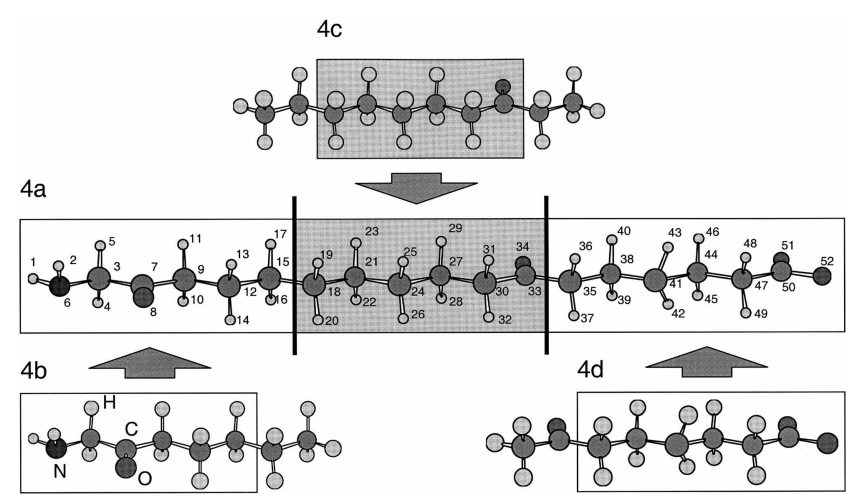

Figure 4. $\mathrm{NH}_{2}-\mathrm{C}_{11} \mathrm{O}_{2} \mathrm{II}_{28-}-\mathrm{COO}^{-}$(a) and its fraglinent (b. c. d).

13. The scale factor in eq. 13, $k$, was computed by eq. 9 where $\left.\Delta q\right|_{k-1}$ was obtained from the summation of $q_{A}$. $\left(q_{1}^{\prime}+q_{2}^{\prime}-\cdots q_{12}^{\prime}\right)$. Note that Coulson chatges of the neighboring atoms of these 2 fragments (from $q_{17}$ ' to $q_{23}$ ' in Figure $1 b$, and $q_{4}$ and $q_{11}$ to $q_{10}$ in Figure $\left.l_{c}\right)$ were not involved in the consiruction of those of $\mathrm{C}_{10} \mathrm{H}_{22}$.

Nex1 four larget molecules, $\mathrm{NI}_{2}-\mathrm{C}_{10} \mathrm{O}_{2} \mathrm{I}_{28}$-COOH (Figure 2) and its cationic (Figure 3), anionic (Figute 4) and zwitterionic (Figure 5) forms, were constructed from 3 fragment molecules. The left (Figure 2b, 3b, $4 b$ and 5 b), middle (Figure 2c, 3c, 4c and 5c) and right (Figure 2d, 3d, 4d and 5d) fragment molecules of these compounds also included 2 nearest neighbors. The FR charges of the conjugated model (Figure 6), aglycoristocetin (Figure 7), the polyptopylene model complexed with zirconocene (Figute 8), magainin

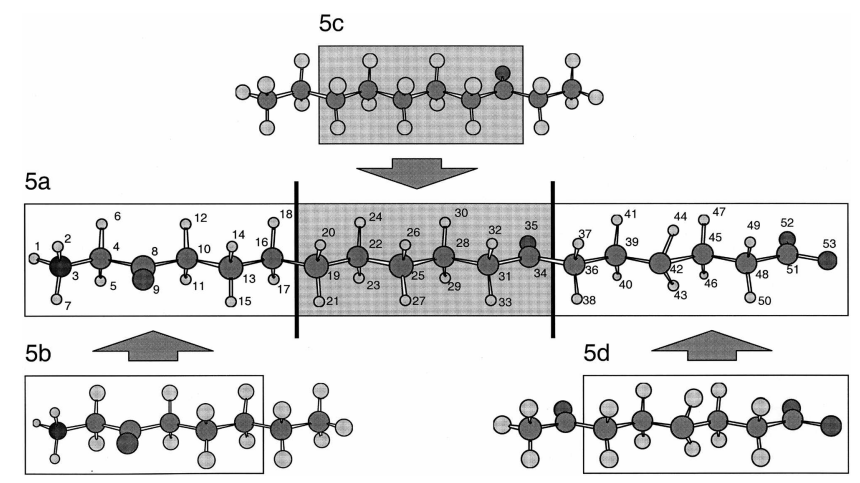

Figure 5. $\mathrm{NII}_{2}{ }^{\prime}-\mathrm{C}_{16} \mathrm{O}_{2} \mathrm{II}_{28}-\mathrm{COO}^{-}$(a) and its fragment (b. c. d).

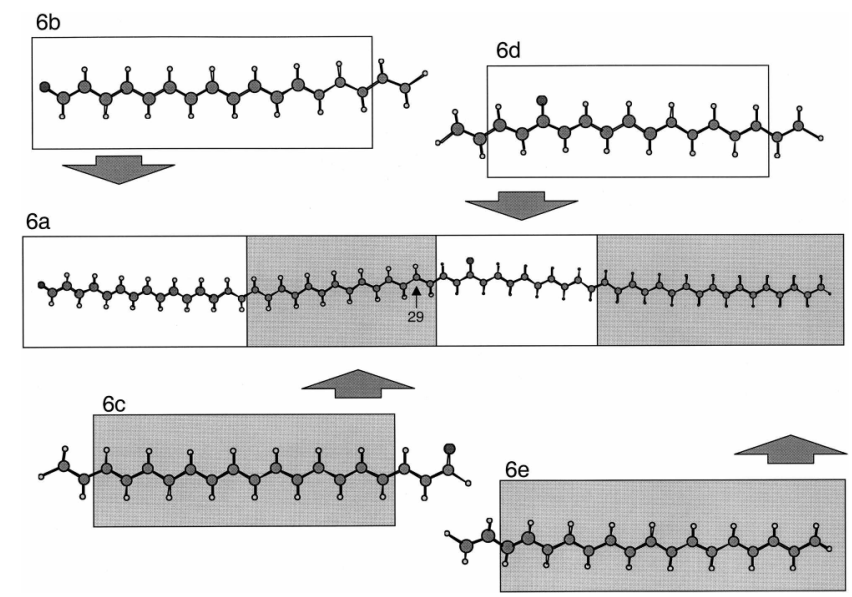

Figure 6. Conjugated model (a) and its fragment (b. c. d. e).

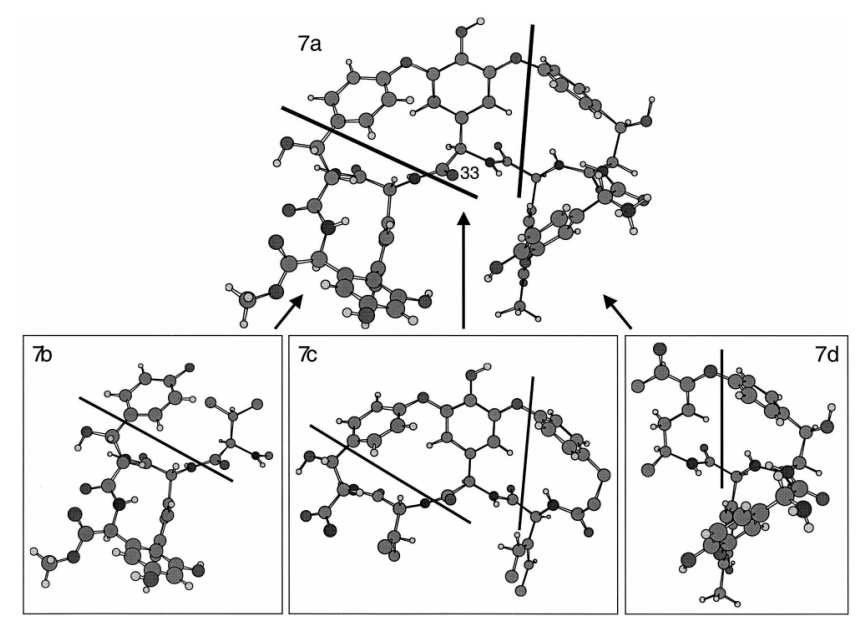

Figure 7. Aglycoristocetin (a) and its fragment (h. c. d).

(Figure 9) and B-DNA (Figure 10) were composed of 4 (Figure 6b, 6c, 6d and 6e), 3 (Figure 7b, 7c and 7d), 4 (Figure 8b, 8c, 8d and 8e), 6 (Figure 9b, 9c, 9d, 9c, 96 and $9 \mathrm{~g}$ ) and 4 (Figire $10 \mathrm{~b}, 10 \mathrm{c}, 10 \mathrm{~d}$ and $10 \mathrm{e}$ ) fragments, respectively. For the conjugated model, aglycoristocetin, the polypropylene model complexed with zirconocene and magainin. each fragment molecule included 2 10 4 nearest neighbors. For B-DNA, each fragment molecule included the nearest amino acid pair(s). 


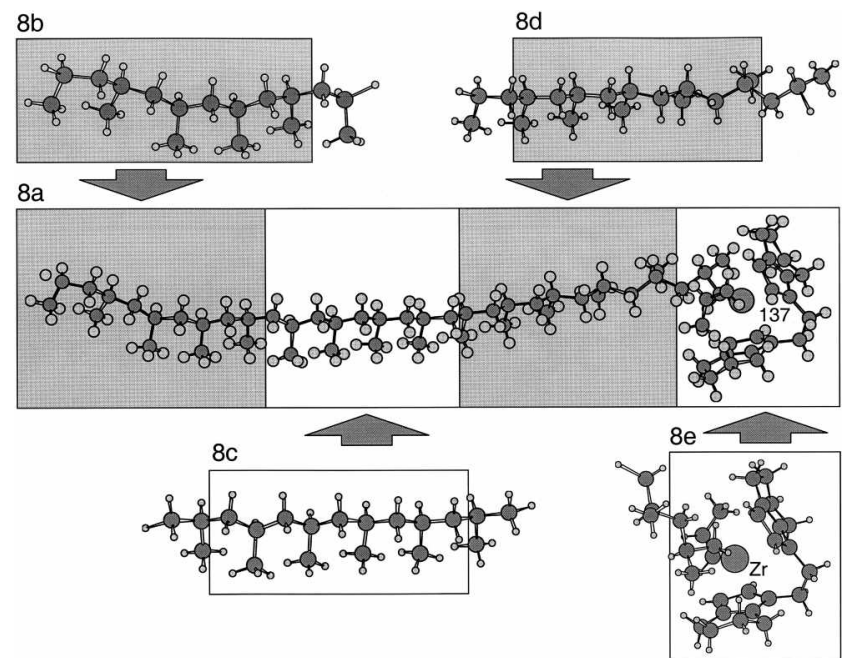

Figure 8. Polypropylene model complexed with a zitconocene (a) and its fragment $\left(b, c, d, c^{2}\right)$.

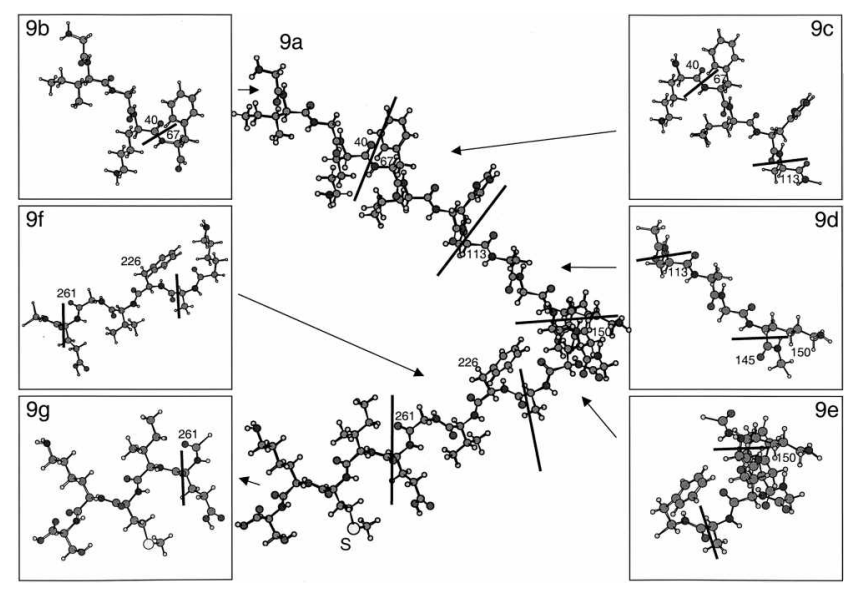

Figure 9. Magainin (a) and its Iragment (b, c, d, e, i, g).

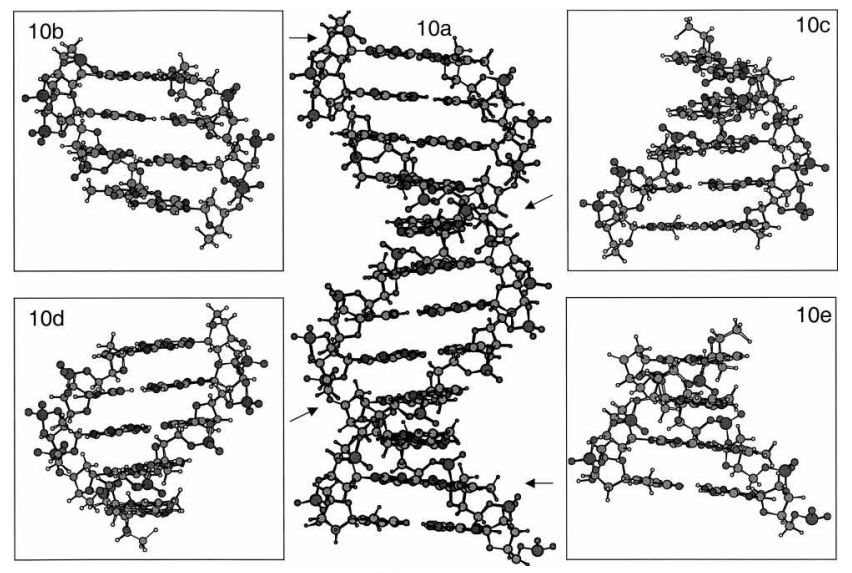

Figure 10. B-DNA (a) and ils fragment (b, c, a. c).

\section{Results and Discussion}

The nomal-ZINDO and FR-ZINDO charges of $\mathrm{C}_{1 \mathrm{i}} \mathrm{H}_{\Perp}$ are listed in Table 1. Maximum differences between these net atomic charges occurred on two carbon atoms $(\mathrm{Cl}+$ and
Table 1. Partial Atomic Charges of ( ${ }_{10} \mathrm{H}_{10}(\angle I N L)$ )

\begin{tabular}{|c|c|c|c|c|}
\hline Atom & Elcment & ZINDO & FR-ZINDO & Ditterence \\
\hline 1 & 11 & 0.0320 & 0.0317 & -0.00002 \\
\hline 2 & $C^{\prime}$ & -0.1130 & $-(1.11+2$ & -0.0012 \\
\hline 3 & $C$ & -0.0650 & $-0.00,02$ & -0.0012 \\
\hline 4 & $C$ & -0.0680 & -0.0692 & -0.0012 \\
\hline 5 & $\mathrm{H}$ & 0.0360 & 0.0357 & $-0,0002$ \\
\hline 6 & $\mathrm{H}$ & 0.0360 & 0.0357 & -0.0002 \\
\hline 7 & $\mathrm{H}$ & 0.0370 & 0.0367 & -0.0002 \\
\hline 8 & $\mathrm{H}$ & 0.0370 & 0.0367 & -0.0002 \\
\hline 9 & $\mathrm{H}$ & 0.0360 & 0.0357 & $-0,0002$ \\
\hline 10 & II & 0.0360 & 0.0 .357 & -0.0002 \\
\hline 11 & $C^{\prime}$ & -0.0690 & $-(100692$ & -0.0002 \\
\hline 12 & II & 0.0350 & 0.0 .357 & 0.00007 \\
\hline 1.3 & II & 0.0350 & 0.0 .357 & 0.00007 \\
\hline 14 & $C^{\prime}$ & $-0.0700)$ & -0.06882 & 0.0017 \\
\hline 15 & II & 0.0350 & 0.0 .357 & 0.00007 \\
\hline 16 & II & 0.0350 & 0.0 .357 & 0.00007 \\
\hline 17 & $\mathrm{C}$ & -0.0700 & -0.0682 & 0.0017 \\
\hline 18 & $\mathrm{H}$ & 0.0350 & 0.0357 & 0.00007 \\
\hline 19 & $\mathrm{H}$ & 0.0350 & 0.0357 & 0.0007 \\
\hline 20 & $\mathrm{C}$ & -0.0690 & -0.0692 & -0.0002 \\
\hline 21 & $\mathrm{H}$ & 0.0350 & 0.0357 & 0.00007 \\
\hline 22 & $\mathrm{H}$ & 0.0350 & 0.0357 & 0.0007 \\
\hline 23 & $C^{\prime}$ & -0.0670 & $-(1.0682$ & -0.0012 \\
\hline 24 & II & 0.0360 & 0.0 .357 & -0.00002 \\
\hline 25 & II & 0.0360 & 0.0 .357 & -0.00002 \\
\hline 26 & $C^{\prime}$ & $-0.0660)$ & $-(1.0672$ & -0.0012 \\
\hline 27 & II & 0.0350 & 0.0 .347 & -0.0002 \\
\hline 28 & 11 & 0.0350 & 0.0 .347 & -0.0002 \\
\hline 29 & $C$ & -0.1140 & -0.1152 & -0.0012 \\
\hline 30 & $\mathrm{H}$ & 0.0350 & 0.0347 & $-0,0002$ \\
\hline 31 & $\mathrm{H}$ & 0.0350 & 0.0347 & $-0,0002$ \\
\hline 32 & $\mathrm{H}$ & 0.0320 & 0.0317 & -0.0002 \\
\hline
\end{tabular}

Standard deviation 0.0008

Scalc factor $\quad 1.0003065$

aR-7.NDDO-7.NDO

C17) near the junction (solid line) in Figure la. The standard deviation (SD) between the ZINDO and FR-ZINDO charges turned out to be very small (0.0008). In comparison. the SD between the normal and FDM ab initio charges of $\mathrm{C}_{k i} \mathrm{H}_{22}$ derived from the ESP fit was much larger $(0.0173) .=$

In Table 2. both ZINDO and FR-ZINDO net atomic charges of $\mathrm{NH}_{2}-\mathrm{C}_{16} \mathrm{O}_{2} \mathrm{H}_{2 x}-\mathrm{COOH}$ are listed. The $\mathrm{SD}$ of the FR-ZINDO charges of this polar molecule was again smaller $(0.0012)$ but larger than that of the non-polar molecule $\left(\mathrm{C}_{1(\mathrm{i}} \mathrm{H}_{2}\right)$. In order to see the fragment effect, we also computed the SD of the FR-ZINDO charges of $\mathrm{NH}_{2-}$ $\mathrm{C}_{16} \mathrm{O}_{2} \mathrm{H}_{2}-\mathrm{COOH}$ with 2 fragments. This $\mathrm{SD}$ turned out to be 0.0007 . Therefore, the error of the polar molecule by the FRZINDO method was affected by the choice of fragments rather than the polarity of molecules. The SDs of the FRZINDO charges of the cationic form $\mathrm{NH}_{3}{ }^{\prime} \mathrm{C}_{1 \leqslant} \mathrm{O}_{2} \mathrm{H}_{2}-\mathrm{COOH}$ and the anionic form $\mathrm{NH}_{2}-\mathrm{C}_{16} \mathrm{O}_{2} \mathrm{H}_{2 \times}-\mathrm{COO}^{-}$were $0.001+$ and 0.0017. respectively. The $\mathrm{SD}$ of the zwitterionic form. $\mathrm{NH}_{\mathrm{i}}$ $\mathrm{C}_{16} \mathrm{O}_{2} \mathrm{H}_{2}-\mathrm{COO}^{-}$. became even larger $(0.0019)$ than that of the singly anionic or cationic form. Compared to the SD of the neutral form $\left(\mathrm{NH}_{2}-\mathrm{C}_{16} \mathrm{O}_{2} \mathrm{H}_{2}-\mathrm{COOH}\right)$. the $\mathrm{SD}^{\prime} \mathrm{s}$ of the 
Table 2. Partial $\Lambda$ tomic Charges of $\mathrm{NH}_{2}-\mathrm{C}_{10} \mathrm{O}_{2} \mathrm{H}_{2 \times}-\mathrm{COOH}$ $(\angle \mathrm{INLO})$

\begin{tabular}{|c|c|c|c|c|}
\hline Atom & Element & ZINDO & FR-ZINDO & Ditterence" \\
\hline ] & II & 0.1660 & 0.1657 & $-1) .0002$ \\
\hline 2 & $\mathrm{~N}$ & -0.4430 & -0.4447 & -0.0017 \\
\hline 3 & $C^{\prime}$ & 0.0520 & 0.0507 & -()$, 0) 12$ \\
\hline 4 & $\mathrm{H}$ & 0.0490 & 0.0486 & -0.0003 \\
\hline 5 & 11 & 0.0530 & 0.0526 & $-(1), 0(0) 3$ \\
\hline 6 & $\mathrm{H}$ & 0.1800 & 0.1797 & -0.0002 \\
\hline 7 & $C^{\prime}$ & 0.3000 & 0.3898 & 1) \\
\hline 8 & 0 & -0.5080 & $-0.5(1990)$ & $-(0.0010$ \\
\hline 9 & $\mathrm{C}$ & -0.0560 & -0.0562 & -0.0002 \\
\hline 10 & 11 & 0.0440 & 0.11436 & $-(1), 0(0) 3$ \\
\hline 11 & $\mathrm{H}$ & 0.0450 & 0.0446 & -0.0003 \\
\hline 12 & C: & -0.0570 & $-(1.6157 .3$ & -0.0003 \\
\hline 13 & $\mathrm{H}$ & 0.0460 & 0.0466 & 0.0006 \\
\hline 14 & 11 & 0.0460 & 0.01460 & 0.0000 \\
\hline 15 & $C$ & -0.0660 & -0.0643 & 0.0016 \\
\hline 16 & 11 & 0.0340 & 16.11340 & 0.0000 \\
\hline 17 & $\mathrm{H}$ & 0.0350 & 0.0346 & -0.0003 \\
\hline 18 & $C$ & -0.06000 & $-(1) .0653$ & 0.0006 \\
\hline 19 & $\mathrm{H}$ & 0.0350 & 0.0336 & -0.0013 \\
\hline 20 & $\mathrm{H}$ & 0.0350 & 0.0336 & -0.0013 \\
\hline 21 & $C$ & -0.00600 & $-(1) .1) 663$ & -0.0003 \\
\hline 22 & $\mathrm{H}$ & 0.0350 & 0.0366 & 0.0016 \\
\hline 23 & II & 0.0 .350 & (1). 1360 & 0.0016 \\
\hline 24 & $\mathrm{C}$ & -0.0680 & -0.0693 & -0.0013 \\
\hline 25 & II & 0.0320 & 0.0306 & -0.0013 \\
\hline 26 & $\mathrm{H}$ & 0.0320 & 0.0306 & -0.0013 \\
\hline 27 & $C^{\prime}$ & -0.00330 & $-(1) .06 .3 .3$ & -0.0003 \\
\hline 28 & $\mathrm{H}$ & 0.0450 & 0.0456 & 0.0006 \\
\hline 29 & II & 0.0450 & (1). 10.456 & 0.0006 \\
\hline 30 & $\mathrm{C}$ & -0.0570 & -0.0562 & 0.0007 \\
\hline 31 & $\mathrm{H}$ & 0.0450 & 0.0456 & 0.0006 \\
\hline 32 & II & $0.045 t)$ & (1). 14.456 & 0.0000 \\
\hline 33 & $\mathrm{C}$ & 0.3840 & 0.3878 & 0.0038 \\
\hline 34 & 0 & -0.5160 & $-(1.51 .30$ & 0.0029 \\
\hline 35 & $\mathrm{C}$ & -0.0520 & -0.0502 & 0.0017 \\
\hline 36 & 11 & $0.0460)$ & 10.1466 & 0.0000 \\
\hline 37 & $\mathrm{H}$ & 0.0450 & 0.0456 & 0.0006 \\
\hline 38 & $\mathrm{C}$ & -0.0850 & $-(1) .1853$ & -0.0003 \\
\hline 39 & $\mathrm{H}$ & 0.0190 & 0.0196 & 0.0006 \\
\hline 40) & 11 & 0.0190 & 0.10196 & 0.0006 \\
\hline 41 & $\mathrm{C}$ & -0.4390 & -0.4404 & -0.0014 \\
\hline 42 & 11 & 0.2110 & 0.2117 & 0.0007 \\
\hline 4.3 & 11 & 0.2110 & 0.2107 & -0.00002 \\
\hline 44 & $\mathrm{C}$ & 0.0160 & 0.0147 & -0.0012 \\
\hline 45 & 11 & 0.0410 & 0.04166 & -0.000 .3 \\
\hline 46 & $\mathrm{H}$ & 0.0410 & 0.0406 & -0.0003 \\
\hline 47 & $\mathrm{C}$ & -0.0 .310 & -6.0 .322 & $-(0.0012$ \\
\hline 48 & $\mathrm{H}$ & 0.0640 & 0.0637 & -0.0003 \\
\hline 49 & 11 & 0.0640 & 0.06 .37 & -0.0003 \\
\hline 50 & $\mathrm{C}$ & 0.5490 & 0.5478 & -0.0011 \\
\hline 51 & 0 & $-(0.5900)$ & -0.60111 & -0.0021 \\
\hline 52 & 0 & -0.3230 & -0.3250 & -0.0020 \\
\hline 5.3 & 11 & 0.26 .30 & 0.2627 & -0.00002 \\
\hline
\end{tabular}

Standard deviation 0.0012

Scalc factor $\quad 1.0003204$ cationic. anionic and zwitterionic forms were increased by 17. 42 and $58 \%$. respectively. For these compounds. large differences between the ZINDO and FR-ZINDO charges were found on the carbon and oxygen atoms of the $>C=O$ group near the right junction in Figure 2 to Figure 5.

The SD $(=0.0024)$ of the conjugated model turned out to be rather large for a neutral molecule. The SD $(=0.0038)$ of aglyconistocetin (cationic form) was largest among all models. Here. we wanted to check how much error was contributed from the ionic effect only: So. the ZINDO and FR-ZINDO charges of the neutral form $\left(\mathrm{C}_{x \rightarrow 1} \mathrm{~N}=\mathrm{O}_{1} \mathrm{H}_{51} .137\right.$ atoms) were calculated. The SD of the FR-ZINDO charges of the neutral form was greatly reduced $(\mathrm{SD}=0.0013)$ compared with that of the cationic form. The error calused by the ionic effect of aglycoristocetin was much larger than that of $\mathrm{NH}_{3}{ }^{\prime} \mathrm{C}_{16} \mathrm{O}_{2} \mathrm{H}_{2 x}-\mathrm{COOH}$. For the polypropylene model complexed with zirconocene (cationic form), the SD of the FR-ZINDO charges was 0.0023 . which was larger than that ( $\mathrm{SD}=0.0014$ ) of $\mathrm{NH}_{3} \mathrm{C}_{16} \mathrm{O}_{5} \mathrm{H}_{2 x}-\mathrm{COOH}$, but smaller than that of aglycoristocetin. ln other words. as the degree of linearity of a molecule (such as $\mathrm{NH}_{3}{ }^{\prime} \mathrm{C}_{16} \mathrm{O}_{2} \mathrm{H}_{2 \times}-\mathrm{COOH}$ or $\mathrm{C}_{6 \times 8} \mathrm{H}_{12]} \mathrm{Zr}$ ) increased. the error of the charges obtained by the FRZINDO method decreased. For magainin. the SD of the FR$Z I N D O$ charges was also small ( $S D=0.0013$ ). The reason for the small SD is that magainin has a V-shape being considered as a combination of two linear molecules. The CPU time of the conjugated model. agly coristocetin. the polypropylene model complexed with zirconocene or magainin by the FRZINDO turned out to be. respectively: $4.2,6$ or 21 times faster than that by the normal ZINDO method. In general. the more the molecular size is increased, the more the CPU saving by the FR method is. Also. the more the number of fragments of a molecule is increased. the more the CPU saving by the FR method is.

As shown in Table 3, the $\mathrm{SD}(=0.0016)$ of $\mathrm{C}_{14} \mathrm{H}_{22}$ between the MP2 and FR-MP2 Mulliken charges was larger than that $(=0.0008)$ between the ZINDO and FR-ZINDO charges. The SD of $\mathrm{C}_{10} \mathrm{H}_{22}$ between the MP2 and FR-MP2 Natural charges was also 0.0016 . However. these SD's of of $\mathrm{C}_{14} \mathrm{H}_{22}$ were still much smaller than in the cases of the FDM-ESP fit as described earlier. As shown in FR-ZINDO calculations of $\mathrm{C}_{1} \mathrm{H}_{22}$, lange differences between the MP2 and FR-MP2 charges in both MPA and NPA also took place on the carbon atoms $(\mathrm{Cl} 4$ and $\mathrm{Cl}$ ) near the junction. The SD's $(=0.0019$ and 0.0033$)$ of $\mathrm{NH}_{2} \mathrm{C}_{16} \mathrm{O}_{2} \mathrm{H}_{2 x}-\mathrm{COOH}$ and $\mathrm{NH}_{3}-\mathrm{C}_{161} \mathrm{O}_{2} \mathrm{H}_{2 x-}$ $\mathrm{COO}^{-}$between the MP2 and FR-MP2 Mulliken charges were again larger than those $(=0.0012$ and 0.0019$)$ between the ZINDO and FR-ZINDO charges. The SD's $(=0.001+$ and $0.0023)$ of $\mathrm{NH}_{2} \mathrm{C}_{16} \mathrm{O}_{2} \mathrm{H}_{28}-\mathrm{COOH}$ and $\mathrm{NH}_{3}{ }^{\prime}-\mathrm{C}_{16} \mathrm{O}_{2} \mathrm{H}_{2 x}-\mathrm{COO}^{-}$ between the MP2 and FR-MP2 Natural charges were smaller than those between MP2 and FR-MP2 Mulliken charges. The CPU time of $\mathrm{NH}_{2} \mathrm{C}_{1 \leqslant} \mathrm{O}_{2} \mathrm{H}_{2 x}-\mathrm{COOH}$ and $\mathrm{NH}_{3}-\mathrm{C}_{1 \leqslant} \mathrm{O}_{2} \mathrm{H}_{28-}$ $\mathrm{COO}^{-}$by the FR-MP2 calculations was, respectively, 6 and 20 times faster than that by the coirentional MP2 calculations. Large errors of the FR-MP2 charges of these two compounds were found on the carbon and oxygen atoms near the right junctions in Figure 2 and Figure 5. 
Table 3. Partial Atomic Charges ol C C $113 \mathrm{H}_{11}(\mathrm{MP} 2)$

\begin{tabular}{|c|c|c|c|c|c|c|c|}
\hline \multirow{2}{*}{ Atom } & \multirow{2}{*}{ Element } & \multicolumn{3}{|c|}{ Mulliken Charge } & \multicolumn{3}{|c|}{ Natural Charge } \\
\hline & & MP2 & lik-MP2 & Diflerence ${ }^{\alpha}$ & MP2 & 1.R-MP2 & Dillerence? \\
\hline ] & 11 & 0.1561 & 0.1567 & 0.001016 & 0.20141 & 0.20145 & 0.0001 .4 \\
\hline 2 & $C^{2}$ & $-1) .4756$ & -1).4769 & $-(0.001) 3$ & -0.5978 & $-(1.5982$ & -0.0004 \\
\hline 3 & $\mathrm{c}$ & -0.2822 & $-1) .28 .37$ & $-(0.0)(115$ & $-(0.3839$ & $-(1.3844$ & -0.00005 \\
\hline 4 & C & -0.2854 & -0.2870 & $-(1)(1)(1) 6$ & -0.3926 & $-(1.39 .31$ & -0.00005 \\
\hline 5 & 11 & 0.1532 & 0.15 .34 & $0.00(1) 2$ & 0.1973 & 0.1974 & 0.0001 \\
\hline 6 & 11 & 0.1532 & 0.1534 & $0.00(1) 2$ & 0.1974 & 0.1976 & 0.00002 \\
\hline 7 & $\mathrm{H}$ & 0.1480 & 0.1485 & 0.0005 & 0.1936 & 0.1939 & 0.0003 \\
\hline 8 & $\mathrm{H}$ & 0.1481 & 0.148 .5 & 0.0004 & 0.1948 & 0.1951 & 0.0003 \\
\hline 9 & $\mathrm{H}$ & 0.1446 & 0.1452 & 00006 & 0.1942 & 0.1945 & 0.0003 \\
\hline 10 & $\mathrm{H}$ & 0.1446 & 0.1452 & 0.0006 & 0.1921 & 0.1924 & 0.00003 \\
\hline 11 & $\mathrm{C}$ & -0.2898 & -0.2903 & -0.0005 & -0.3893 & -0.3883 & 0.0010 \\
\hline 12 & $\mathrm{H}$ & 0.1448 & 0.1468 & 0.0020 & 0.1936 & 0.1949 & 0.0013 \\
\hline 13 & $\mathrm{H}$ & 0.1448 & 0.1468 & 0.0020 & 0.1950 & 0.1963 & 0.0013 \\
\hline 14 & $c^{\prime}$ & -0.2898 & -0.29 .37 & -0.0039 & -0.3888 & $-(1.3949$ & -0.0061 \\
\hline 15 & 11 & 0.1450 & 0.1456 & 0.0006 & 0.1934 & 0.1933 & -0.00001 \\
\hline 16 & 11 & 0.1449 & 0.1456 & 0.0007 & 0.1967 & 0.1979 & 0.0012 \\
\hline 17 & $C^{\prime}$ & -0.2900 & -0.2946 & -0.0046 & -0.3892 & $-(1.39+6$ & -0.0054 \\
\hline 18 & II & 0.1449 & 0.1458 & 0.00069 & 0.1954 & 0.1964 & 0.0010 \\
\hline 19 & II & 0.1449 & 0.1458 & 0.00069 & 0.1957 & 0.1960 & 0.00003 \\
\hline 20 & $\mathrm{C}$ & -0.2897 & -0.2901 & -0.0004 & -0.3884 & -0.3875 & 0.0009 \\
\hline 21 & $\mathrm{H}$ & 0.1451 & 0.1471 & 0.0020 & 0.1961 & 0.1973 & 0.0012 \\
\hline 22 & $\mathrm{H}$ & 0.1451 & 0.1471 & 0.0020 & 0.1924 & 0.1937 & 0.0013 \\
\hline 23 & $\mathrm{C}$ & -0.2855 & -0.2873 & -0.0018 & -0.3941 & -0.3947 & -0.0006 \\
\hline 24 & $\mathrm{H}$ & 0.1445 & 0.1452 & 0.0007 & 0.1903 & 0.1906 & 0.0003 \\
\hline 25 & $\mathrm{H}$ & 0.1445 & 0.1452 & 0.0007 & 0.1956 & 0.1961 & 0.0005 \\
\hline 26 & $C^{\prime}$ & -0.2852 & -0.2867 & -0.0015 & -0.3844 & $-(1.3848$ & -0.0004 \\
\hline 27 & II & 0.1467 & 0.1472 & 0.00005 & 0.1934 & 0.1937 & 0.00003 \\
\hline 28 & II & 0.1467 & 0.1472 & 0.0005 & 0.1952 & 0.1955 & 0.00003 \\
\hline 29 & $C^{\prime}$ & -0.4759 & -0.4772 & -0.0013 & -0.5961 & -0.5965 & $-0.0(0) 4$ \\
\hline 30 & II & 0.1518 & 0.1520 & 0.00002 & 0.1966 & 0.1967 & 0.00001 \\
\hline 31 & II & 0.1518 & 0.1520 & 0.00002 & 0.1980 & 0.1981 & 0.00001 \\
\hline \multirow[t]{2}{*}{32} & $\mathrm{H}$ & 0.1557 & 0.1563 & 00006 & 0.2035 & 0.2040 & 0.0005 \\
\hline & & $\begin{array}{l}\text { Standard deviation } \\
\text { Scalc factor }\end{array}$ & \multicolumn{2}{|c|}{$\begin{array}{l}0.0016 \\
1.0001647\end{array}$} & \multicolumn{2}{|c|}{$\begin{array}{ll}\text { Standard deviation } & 0.00016 \\
\text { Scale factor } & 1.0000744\end{array}$} & \\
\hline
\end{tabular}

"F.R-MP2-MP2.

\section{Conclusion}

Net atomic charges of several model compounds were calculated by the FR-ZINDO and FR-MP2 methods. These charges were compared with the colnentional ZINDO and MP2 methods, respectively: In the FR-ZINDO calculations, the standard deviations of neutral molecules ( $\mathrm{SD}=0.0008-$ $0.0013)$ except for the conjugated model turned out to be smaller than those of ionic. cationic and zwitterionic compounds ( $\mathrm{SD}=0.0014-0.0038$ ). In both FR-MP2 Mulliken and FRMP2 Natural charge computations. the SD's $(=0.0016-$ $0.0033)$ of $\mathrm{C}_{16} \mathrm{H}_{2} . \mathrm{NH}_{2} \mathrm{C}_{16} \mathrm{O}_{2} \mathrm{H}_{28}-\mathrm{COOH}$ and $\mathrm{NH}_{3}{ }^{1}-\mathrm{C}_{16} \mathrm{O}_{2} \mathrm{H}_{2}-$ $\mathrm{COO}^{-}$were larger than those $(\mathrm{SD}=0.008-0.0019)$ in the corresponding FR-ZINDO Coulson charge computations. These errors depended on the shape of molecules, the degree of ionic characters of molecules the choice of fragment molecules as well as the choice of methods. The SDs (=0.0008-0.0038) of all models by the FR-ZINDO and FRMP2 methods are. hovever. much smaller than those (SD = $0.014-0.021)^{-2-}$ of medium molecules by the FDM ab initio charges derived from the ESP fit. The CPU time by the FRZINDO (or FR-MP2) method tumed out to be much faster than that by the normal ZINDO (or normal MP2) method. Because of the smaller SD and more CPU saving. the FR method. especially the FR-MP2 NPA method would become a choice for systematic charge analyses of huge molecules.

Supplementary Materials Available. The FR-ZINDO and FR-MP2 atomic charges of the large molecules calculated in this work are axailable upon request.

Acknowledgment. The GAUSSIAN98 calculations were carried out at the KUMHO Supercomputing Center in Kwangiu. Korea.

\section{References}

1. Jensen, F. Introduction to Computational Chemistm: Wilev \& Soms: Chichester. 1999: Chapter 9.

2. Rappe, A. K.: Goddard III, W. A.J. Phws. (Th'm. 1991, 95, 3.358 
3. Mulliken. R. S. J. Chtem. Pths. 1955, 23, 1833.

4. Singh. U. C: Kollman. P. A. J. Comput. Chtem. 1984. 5. 129.

5. Sime. A. J.: Alderlon. M. Hol Phy. 1985, 56, 1047.

6. Chirlian, J. F.: Francl, M. M. J. Comput. Chem. 1987. \&.894.

7. Breneman, C. M: Wiberg. K. B. J. C'omput. (hem. 1990. H, 361.

8. William S, D. E. Rev Comput (hem. 1991, 2,219

9. Reynolds. C. A.: Essex. J. W.: Richards. W. G. J. Am. Chom. Soc: 1992. 11. 9075 .

10. Aleman. C.: Orozro. M.: Luque. F. J. Chom. Phns. 1994. 189.573.

11. Koch. U.: Fegert. F. J. ('omput. ('hem. 1995. 16.937

12. Marvinick. D. S. J. Comput Chem. 1997. IS, 955.

13. Swart, M.: Dujinen, P. T. F.: Snijders. J. G. J. Comput. (Them. 2001. 22. 79\%.

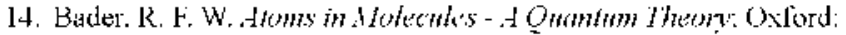
Londen. 1990.

15. Cioslowski, J. J. Am. Chem. Soc. 1989. H11.8333

16. Cioslowski, J. J. Chem. Phss. I.th. 1992. ISO, 524

17. Foster. J. P.: Weinhold, F. J. 1m. (Hem. Soc 1980. 102.7211

18. Reed. A. E.: Weinhold. F. $J$. Ch'm. Phns. 1983. 78.4066.

19. Reed. A. E.: Weinslock. R. B.: Weinhold. F. J. Ch'm. Ihis. 1985. 83.735 .

20. Reed. A. F.: Curtiss, I. A.: Weinhold. Г. ( Then. Rev 1988. 88. 899.

21. Weinhold, F: Carpenter, J. Г. The Structure of Sindl Wolecules andlons: Plenum: 1988: p 227.

22. Lee. J-Gi.: Friesner. R. A. J. Phns. Chom 1993.97.3515.

23. Recently. lle semiempirical devide and conquer method sinilar 10 on f'DM approach was applied to a biological system. See Van der Vaart. A.: Gogonea. V.: Dixon. s. L.: Meř. K. M.. Ir. $J$, Comput. Chtm. 2000. 21. 149.4.

24. Bellido, M. N.: Rullmann. I. A. C. J. ('omput. ('hem. 1989. 10. 479

25. Young, I.: Topol. I. A.; Rashin, A. A.: Burt, S. K. J. Comput. Chem. 1997. 18. 522 .

26. Dardenne. L. E.: Wemedk. A. S.: Oliveira Neto. M.: Bisch. P. M. J. Comput. Chm 2000. 22. 689.

27. 7.INDO, Usser Guide. Fersion 95.0 3.0.0. BIOSYM:Molecular Simulations: 1995

28. Trisch, M. J.: Trucks, G. W.: Schlegel. II. B.: Scuseria, G. F.: Robb. M. A.: Cheeseman. I, R.: Zakrzeuski. V. G.: Montgomery. J. A.: Stratmann. Ir.. R. E.: Burant. J. C.: Dapprich. S.: Millam. I. M.: Daniels. A. D.: Kudin. K. N.: Strain. M. C.: Farkas. O.: Tomasi. I.: Bame, V: Cossi. M.: Cammi. R.: Mentucci. B.: Poncli, C.: Adamo, C.: Clitford, S.: Ochterski. J.: Petersson, C. A.: Myala. P. Y.: Cui. Q.: Morokuma, K.: Malick. D. K.: Rabuck, A. D.: Raghavachari. K.: Foresman. J. B.: Cioslonsti. J.: Ortiz. .l. V: Baboul. A. G.: Stefanor. B. B.: Litu. G.: Lisslenko. A.: P'iskors. P': Komaromi. 1.: Gomperts. R.: Martin. R. L.: Fos. D. I.: Keith. T.: $\Lambda$ l-I aham. M. A.: Peng. C. Y.: Nanavakikara, $\Lambda$. Gonzalez., C.: Challacombe, M.: Gill, P. M. W.: Johnson, B. G.: Chen, W. Wong, M. W.: Andres, J. I.: I Iead-Gordon, M.: Replogle. E. S.: Pople. J. A. Gonssion 98 Ravision A.7). Gaussian. Inc,: P'ittsburgh. P'A. 1998. 